\title{
INTERNATIONAL REGIMES FOR CHILD RIGHTS
}

\author{
Ms. Rachana C. Raval \\ \& \\ Dr. Bhavesh H. Bharad
}

\section{Introduction:}

It was not until the late nineteenth century that a nascent children's rights protection movement countered the widely held view that children were mainly quasi property and economic assets. In the United States, the progressive movement challenged courts reluctance to interfere in family matters, promoted broad child welfare reforms and was successful in having laws passed to regulate child labor and provide for compulsory education. It also raised awareness of children's issues and established a juvenile court system. Another push for children's rights occurred in the 1960s and 1970s, when children were viewed by some advocates as victims of discrimination or as an oppressed group. In the international context, -the growth of children's rights in international and transnational law has been identified as a striking change in the post-war legal landscape. ${ }^{1}$ Children are a - supremely important nation and international asset of the future well-being of the world depends on how the children grow \& develop. United Nations adopted a resolution which proclaimed 1979 as an international year of the child. In consequence of this proclamation, In 1979, the Government of Polland submitted a draft on the rights of child for adoption by U.N. General Assembly as a lasting memorial year of the child after revised version \& a decade campaigning, the UN General Assembly adopted the convention on the rights of the child on November 201989 and ratified by 135 nations including India.

Article 25(2) of the Universal Declaration of Human Rights (UDHR) says that:

Motherhood and childhood are entitled to special care and assistance. All children whether born in, or out of wedlock shall enjoy the same social protection. family, which is the natural and fundamental group unit of society for the care and education of dependent children has been recognized by virtue of Article 10(1) of the Inter Covenant on Economic Social and Cultural Rights (ICESCR). The United Nations Convention on the Rights of the Child, adopted in 1989 to protect the rights of children, is the most widely ratified human

\footnotetext{
${ }^{1}$ Stephen R. Arnott, Family Law: Autonomy, Standing \& Children‘s Rights, 33 William Mitchell Law Review 809
} (2007) 
rights treaty in history. It encompasses civil rights and freedoms, family environment, basic health and welfare, education, leisure and cultural activities and special protection measures for children. The United Nations' 1989 Convention on the Rights of the Child, or CRC, is the first legally binding international instrument to incorporate the full range of human rights - civil, cultural, economic, political and social rights. Its implementation is monitored by the Committee on the Rights of the Child. National governments that ratify it commit themselves to protecting and ensuring children's rights, and agree to hold themselves accountable for this commitment before the international community. ${ }^{2}$

\section{CONVENTION OF THE RIGHTS OF THE CHILD, 1989}

The Convention on the rights of the Child, drafted by the U.N. Commission on Human Rights, was adopted by the General Assembly of the United Nations on $20^{\text {th }}$ November, 1989. The Convention is a set of international standards and measures intended to protect and promote the well being of children in society. The Convention draws attention to four sets of civil, political, social, economic and cultural rights of every child. These rights are:

The Right to Survival: This right includes the right to life, the highest attainable Standards of health, nutrition and adequate standards of living. It also includes the right to a name and a nationality.

The Right to Protection: This includes freedom from all forms of exploitation, abuse, inhuman or degrading treatment and neglect, including the right to special protection in situations of emergency and armed conflicts.

The Right to Development: It contains the right to education, support for early Childhood development and care, social security, and the right to leisure, recreation and cultural activities.

The Right to Participation: It includes respect for the views of the child, freedom of expression, access to appropriate information, and freedom of thought, Conscience and religion.

\section{WORLD SUMMIT FOR CHILDREN, 1990}

The World Summit for Children was a follow-up action to the convention. It was held at the UN Headquarters and was the first ever World Summit which enabled national leaders to focus exclusively on issues affecting the future of Children. Among the goals adopted at this summit were:

(i) Reduction in child deaths and child malnutrition;

(ii) Increasing immunization level;

(iii) Halving maternal mortality; and

(iv) The universal ratification of the Convention on the Rights of the Child.

\footnotetext{
${ }^{2}$ Convention on the rights of child, UNICEF
} 


\section{WORLD CONFERENCE ON HUMAN RIGHTS, 1993}

In the World Conference on Human Rights considerable urgency was expressed for the protection and implementation of the rights of child. The World Conference reiterates the principle of -first call for childrenl. In this respect it underlined the importance of the role of the UNICEF in the protection and promotion of the rights of the child. -Human Rights begin with Children's Rights is the new perception given by the UNICEF for the promotion of rights of the child.

\section{Declaration of the Rights of the Child $1959^{3}$ :}

The UN Declaration of the Rights of the Child (DRC) builds upon rights that had been set forth in a League of Nations Declaration of 1924. The Preamble notes that children need - special safeguards and care, including appropriate legal protection, before as well as after birth, reiterates the 1924 Declaration's that pledge that -mankind owes to the child the best it has to give,l and specifically calls upon voluntary organizations and local authorities to strive for the observance of children's rights. ${ }^{4}$ One of the key principles in the DRC is that a child is to enjoy special protection as well as -opportunities and facilities, by law and by other means, for healthy and normal physical, mental, moral, spiritual and social development -in conditions of freedom \& dignity Minimum Age Convention $1973 .^{5}$

\section{Convention on the Rights of Child 1989:}

The United Nations Convention on the Rights of the Child is a human rights treaty which sets out the civil, political, economic, social, health and cultural rights of children. The convention defines a child as any human being under the age of eighteen, unless the age of majority is attained earlier under a state's own domestic legislation.

\section{European Convention on the Exercise of Children's Rights, 1996:}

The European Convention on the Exercise of Children's Rights (ECECR) stresses in the preamble the aim of promoting the rights and - best interests\| of children. 6 To that end it states that children should have the opportunity to exercise their rights, particularly in family proceedings affecting them; they should be provided with relevant information (defined as information appropriate to the child's age and understanding, given to enable the child to exercise his or her rights fully, unless contrary to the welfare of the child) and their views should be given — due weightll and — where necessaryll, states as well as parents, should engage in the protection and promotion of those rights and best interests(Preamble). The ECECR applies to children who have not reached the age of eighteen.

\section{UNIVERSAL DECLARATION OF HUMAN RIGHTS, 19486:}

\footnotetext{
${ }^{3} \mathrm{http}: / / \mathrm{www} . \mathrm{unh} \mathrm{chr} \cdot \mathrm{ch} / \mathrm{html} / \mathrm{menu} / \mathrm{b} / 25 . \mathrm{htm}$

${ }^{4}$ Geraldine Van Bueren, The International Law on the Rights of the Child

$55 \mathrm{http}: / /$ www2.ohchr.org/english/law/ageconvention.htm

${ }^{6} \mathrm{http} / / /$ conventions.coe.int/Treaty/Commun/QueVoulezVous.asp? 
The Universal Declaration of Human Rights contains two articles that specifically refer to children. Article 25(2) states: -motherhood and childhood are entitled to special care and assistance. All children whether born in or out of wedlock shall enjoy the same special protection. ${ }^{7}$

Article 26 calls for the right to education for all and deals both with access to and the aims of education. Thus education is to be free, at least in the elementary and fundamental stages; elementary education is to be compulsory; and education should be -directed to the full development of the human personality and to the strengthening of respect for human rights and fundamental freedoms.l Nevertheless, -parents have a prior right to choose the kind of education that shall be given to their children.

\section{International Covenant on Economic, Social and Cultural Rights, 1966:}

The preamble to the International Covenant on Economic, Social and Cultural Rights (ICESCR), in so far as it recognizes the indivisibility of human rights is applicable to children's rights as well. Thus, it notes that -recognition of the inherent dignity and of the equal and inalienable rights of all members of the human family is the foundation of freedom, justice and peace in the worldl and that -these rights derive from the inherent dignity of the human personl. ${ }^{9}$ Specific references to children are found in articles 10 and 12.

Under article 10, -the widest possible protection and assistance should be accorded to the family, particularly for its establishment and while it is responsible for the care and education of dependent children.

Article 12 addresses the right of all to -enjoyment of the highest attainable standard of physical and mental health,l to be fully realized by, among other measures, States Parties providing -for the reduction of the stillbirth- rate and of infant mortality and for the healthy development of the child.

\section{International Covenant on Civil and Political Rights, 1966 $^{10}$ :}

The international Covenant on Civil and Political Rights (ICCPR) contains general provisions from which children are entitled to benefit as well as certain specific provisions on safeguards for children in the administration of justice and as members of a family unit. Thus, article 2 obliges States Parties - to respect and to ensure to all individuals within its territory and subject to its jurisdictionl the rights recognized in the ICCPR, -without distinction of any kind to adopt laws to give effect to those rights; and to provide effective remedies where there are violations.

Like the ICESCR, the ICCPR recognizes the family as entitled to societal and state protection

\footnotetext{
${ }^{7}$ http://www.un.org/overview/rights.html

${ }^{8}$ Van Bueren, supra note 3, at 18.

${ }^{9} \mathrm{http}$ ///www.ohchr.org/english/law.ccpr.htm

${ }^{10}$ Id. See also Van Bueren, supra note 3
} 
(Article 23(1)) and so State Parties are to respect the liberty of parents to ensure their children's religious and moral education in conformity with their own convictions (Article 18(4)). If a marriage is dissolved, provision must be made for the protection of any children (Article 23(4)).

Article 24 of the ICCPR is specifically devoted to children. It stipulates that -every child shall have, without any discrimination as to race, color, sex, language, religion, national or social origin, property or birth, the right to such measures of protection as are required by his status as a minor, on the part of his family, society and the State.l it further prescribes that every child must be registered immediately after birth and have a name and that every child has the right to acquire a nationality.

\section{Hague Convention on Jurisdiction, etc., for the Protection of Children, 1996 $^{11}$ :}

The Hague Convention on Jurisdiction, Applicable Law, Recognition, Enforcement and Cooperation in respect of Parental Responsibility and Measures for the Protection of Children (1996 Convention) covers a wide range of civil child protection measures, $\|$ from orders concerning parental responsibility and contact to public measures of protection or care and from matters of representation to the protection of children's property. ${ }^{12}$

The Preamble confirms -that the best interests of the child are to be a primary consideration. Article 2 stipulates that the convention is applicable -to children from the moment of their birth until they reach the age of 18 years.

\section{Hague Convention on Jurisdiction, etc., Relating to Adoptions, 1965:}

The Hague Convention on Jurisdiction, Applicable Law and Recognition of Decrees Relating to Adoptions (1965 Convention), the first Hague Convention on the issue, apparently has no contracting parties at present. The Convention is applicable -to all international adoptions, not only where a child originated from another country but also to adoptions where the only international aspect is the foreign nationality of the child. ${ }^{13}$ It has been characterized as incorporating four important provisions. The authorities are not to grant an adoption -unless it will be in the interest of the childl. Before granting an adoption, the authorities should conduct -a thorough inquiry\| relating to the adopter(s), the child, and the child's family. The inquiry should be carried out — as far as possible... in cooperation with public or private organizations qualified in the field of inter- country adoptions $\|$ and with the help of specially trained or qualified social workers (article 6).

\footnotetext{
${ }^{11}$ www.ohchr.org/english/law/ccpr.htm

12 http://www.law.yale.edu/rcw/

${ }^{13}$ Van Bueren, supra note 3, at 98
} 
Towards Excellence: An Indexed, Refereed \& Peer Reviewed Journal of Higher Education / Ms. Rachana Raval \& Dr. Bhavesh Bharad / Page 229-236

\section{European Convention on the Adoption of the Children, 197914:}

The European Convention on the Adoption of the Children (ECAC) applies to the legal adoption of the children under the age of 18, not currently or previously married and not deemed in law to have come of age earlier (Article 3). Its provisions are only minimum standards; States Parties may adopt provisions more favorable to the adopted child (Article 16). ${ }^{15}$

The ECAC ensures that national child protection laws apply not only to adoptions of children from the States Parties, but also to those of children from other states. The essential provisions are on adoption practices that each party should undertake to incorporate in national legislation.

Under them, adoption must be granted by a judicial or administrative authority in order to be valid (Article 7) and the competent authority should not grant an adoption unless it -will be in the interest of the child\| (Article 8(1)). The authority is to make appropriate inquiries into such matters as the child's views with respect to the adoption and the mutual suitability of the child and the adopter (Article 9). After the adoption, the child should generally be able to acquire the adopter's surname and be treated as having rights of succession (Article 10(3) and (5)). States Parties should prohibit any improper financial advantage arising from a child being given up for adoption (Article 15).

\section{Hague Convention on the Civil Aspects of International Child Abduction, 1980:}

The Hague Convention on the Civil Aspects of International Child Abduction (1980 Convention) governs issues related to parental kidnapping or the removal of children under the age of 16 across international borders and involving the jurisdiction of different countries courts. Its stated objectives are to secure the prompt return of children wrongfully removed to or ensure that the rights of custody and of access under the law of one contracting state are effectively respected in the other contracting states (Article 1) Removal or retention of a child is deemed wrongful if:

a) it is in breach of custody rights attributed to a person, an institution, or any other body, either jointly or alone, under the law of the state in which the child was habitually resident immediately before the removal or retention; and

b) At the time of removal or retention those rights were exercised, or would have been but for the removal or retention (Article 3, paragraph 1).

\section{The European Convention concerning the custody of Children, $1980^{16}$ :}

The European Convention on the Recognition and Enforcement of Decisions Concerning the custody of children seeks to protect the rights of custody and access to children in the international context. It calls upon the central authorities designated by States Parties to provide free, prompt, non- bureaucratic assistancell in determining the whereabouts and restoring

\footnotetext{
${ }^{14} \mathrm{http}: / /$ Conventions.coe.int/treaty/en/treaties/html/058.htm

${ }^{15}$ Van Bueren, supra note 3, at 99

${ }^{16} \mathrm{http}: / /$ conventions.coe.int/Treaty/EN/Treaties/Html/105.htm
} 
custody of an improperly removed child. ${ }^{17}$ They must also avoid prejudice to the interests of the child or of the applicant in restoring child custody, among other requirements. Like the 1980 Convention, the Luxemburg Convention defines a child as being under the age of sixteen (Article 1(a)). Also, under both instruments, the right of action lies with the custody holder. ${ }^{18}$

\section{Hague Convention on the Protection of Children in Inter-country Adoption, 1993:}

The Hague Convention on the Protection of Children \& Cooperation in Respect of Intercountry Adoption (1993 Convention), has three stated aims:

- To establish safeguards to ensure that inter-country adoptions are in the best interest of the child and in accordance with the child's fundamental rights;

- To establish a system of safeguards to avoid abuses such as trafficking in children;

- To secure recognition in States Parties of adoptions made in accordance with the Convention. (Article 1).

\section{ENFORCEMENT OF INTERNATIONAL INSTRUMENTS IN INDIA:}

The Government of India has ratified the Convention on the Rights of the Child on 12 November 1992. It has also endorsed the twenty- seven survival and development goals for the year 2000 laid down by the World Summit for children.

Article 73 of the Constitution states: Subject to the provisions of this constitution, the executive power of the Union shall extend to the matters with respect to which Parliament has power to make laws and to the exercise of such rights, authority and jurisdiction as are exercisable by the Government of India by virtue of any treaty or agreement.

Article 253 of the Constitution states that Parliament has power to make any law for the whole or any part of the territory of India for implementing any treaty, agreement to Convention with any other country or countries or any decision makes at any international, conference, association or other body.

In the case of Vishakha v. State of Rajasthan the Supreme Court reiterated the principle that in the absence of a domestic law the contents of international conventions and norms are relevant for the purpose of interpretation of the fundamental rights.

It is significant to note that with the exception of the UN Convention of the Rights of the Child, 1989, there is no other child- centered approach and second, the Asia region, which has the highest proportion of the World's children, does not have any similar regional human rights or child rights instrument. All the countries have ratified the UN Convention on the Rights of the Child.

\footnotetext{
${ }^{17}$ Detrick, A commentary on the Un Convention on the Rights of the Child

${ }^{18}$ Van Bueren, supra note 3, at 90-92
} 


\title{
CONCLUSION:
}

From the above discussions the following conclusions can be derived. This study shows that many crucial aspects of child protection in India are influenced and guided by the existing cultural norms. May it be disciplining the child or taking care of them in the absence of their parents, family (which also includes extended family) is seen as the primary caregiver families. Moreover, mention may be made here of the awareness level of not only the common people but also the policy makers in the countries which highly influences these practices. In case of India, public awareness is very poor. This thus points to the greater role that government has to play to not only create trust but also enforce awareness and understanding of child rights and protection. In states like India, thus the role of nongovernmental organizations, local or international in child protection, cannot be overemphasized. In this respect, it suffices to mention that India also lacks agencies required for strong and effective monitoring and detection of child violence in families. However, the study and its revelation called for intensive intervention and stronger laws for India in order to protect children against violence in families. This also stems from the fact that issues like poverty and child labor are very complex and need to be addressed at the root. Policies, programs and structures to prevent children from falling into difficult circumstances are mostly lacking. This calls for policies aiming at strengthening and empowering the poor and vulnerable families to cope with economic and social adversities and challenges and thus be capable to protect their children and initiate efforts to raise awareness of public on child rights and child protection situation and issues.

\author{
Ms. Rachana C. Raval \\ Research Scholar, \\ University School of Law, Gujarat University, Ahmedabad \\ rachanacraval@yahoo.com \\ \& \\ Dr. Bhavesh H. Bharad \\ Assistant Professor, \\ University School of Law, Gujarat University, Ahmedabad \\ dr.bharad@gmail.com
}

